\title{
Review of Literature on Learners' Personality in Language Learning: Focusing on Extrovert and Introvert Learners
}

\author{
Maryam Cheraghi Shehni \\ Department of Language Teaching and Translation, Islamic Azad University, Varamin-Pishva Campus, Varamin, Iran \\ Tahereh Khezrab \\ Department of Language Teaching and Translation, Islamic Azad University, Varamin-Pishva Campus, Varamin, Iran
}

\begin{abstract}
The improvement in learning English is based on how students are enthusiastic about the subject of English. Learning languages, mainly English, is a great need, even for our primary students who have the responsibility to develop in the globalized world (Muñoz, 2002). These traits are the critical parts of one's personality because they make him unique, and what psychologists have desired to study and measure in the process of learning English as the foreign or second language. Indeed, the variations between individuals, their learning situations and the contexts where they learn are some features that can illustrate the complexity of learning a foreign language. Conversely, in research on the acquisition of foreign languages, it is essential to consider the differences between individuals, their different ways of learning styles and the environment where they are involved.
\end{abstract}

Index Terms—psychology, behavioral differences, introversion, extroversion

\section{INTRODUCTION}

Although many other factors can influence the success of language learning, the personality factor is an internal factor that must not be rejected as the ignorance of the relationship between personality factors, and language learning will have a negative influence on teaching and learning effect. It is claimed that learners bring their emotional states to class, which affects how L2 is achieved and not just their cognitive abilities (Zafar \& Meenakshi, 2012). Likewise, differences in individual learners could principally affect L2 learning results, which in turn increased or decreased L2 learning (Montero et al., 2014). Moreover, from the first days of psychology emergence, it attempts to attain two different and paradoxical objectives: to comprehend the big picture of the mind and to find out the individual differences (IDs) in the minds. The second one leads to a distinct sub-discipline in the psychology historically referred to as differential psychology whereas nowadays it is called individual difference research (ID) (Dornyei, 2005). Nevertheless, over the last decades, researchers have increased research fields and studied crucial aspects in this domain, as well. All through the past, personality has been discussed as the chance of people every time which is the character trait. This meaning provided previously incidentally holds the view that numerous of the decisions people make in their lives are unquestionably associated with their personality trait. This interpretation was mostly whispered by writers who believe in the concept of predictability of the personality. More or less, the scientists held the same view; the only difference was that rather than inevitability, the scientists focused on predictability of the personality (Deutsch et al., 2006).

\section{LITERATURE REVIEW}

As stated by Eysenck (2004), in terms of individuals' performance in numerous practical circumstances, the roles of individual differences in personality are significant. Traits symbolize implicit association between perceptible manners and characteristics to perform. The relations describe the static forms emerged from personal conduct and explain variances among individuals rather than it would be in the individuals, which may result the numerous kinds of feelings, intellects, and performing diverse methods among diverse individuals (Chamorro-Premuzic, 2007, as cited in Ahour \& Haradasht, 2014). Personality, as the character, makes the correspondence between feeling, thought, and conduct. Thus the model of harmonious practice and personal quality, just as the condition of the environment may influence the personal character. Character as the pattern of personal features includes personal adjustment for living, such as significant characteristics, makes values, interests, abilities, self-awareness and feeling models (Cervone \& Pervin, 2010). There are two different ways to define the personality (a) qualities to characterize an person, or as (b) the subordinate system made the different types of attributes (Boyle et al., 2008). At age 3, personality starts to become stable and at age 50, it remains to be indurated. Detecting individuals' personality traits may cause their comprehension of the future behavior (Coon \& Mitterer, 2009). 
Hans Eysenck is a behaviorist who holds that the personality differences are growing out of our inheritance. He was among those people who had always wanted to attack the pre-established ideas; he was brave enough to do so. He questioned the nature of most of the academic varieties of psychology and the effectiveness of psychotherapy (Boeree, 2006). Factors such as psychoticism, extroversion, and neuroticism are the main personality factors which in turn consist of personality traits. Those people who have a high score on psychoticism, are ready to develop psychotic disorders, they are aggressive, egotistical, and tough. Individuals achieving high scores on extroversion are communicative, carefree, and easygoing, consequently those who achieve low scores on the same questions, are labeled as introverts which are said to be asocial and pessimistic but at the same time they are trustworthy. Those who score high on the neuroticism are more in exposure of getting nervous or even depressed. Overall, the accuracy of the EPQ-R is completely based on the honesty of the respondent and it explains the human personality variation (Craighead \& Nemeroff, 2004).

Introversion-extraversion is a definite psychological concept which implying in between phenomena at the biological and social levels and also providing an explanatory connection between them (Wilson, 1977, as cited in Cook, 2002). Recently, and simultaneously different from the stereotypical, Brown (2000), presented introverts and extraverts definition, who defines that extroversion as the amount in which a deep-seated person should receive ego enhancement, self-esteem and a sense of integrity from other people in contrast to receiving such affirmation in oneself. According to Dornyei (2005) and Ellis (2008), the extraversion and introversion dimension is the most researched personality aspect in language studies. This feature is needed to universal personality values, from the Big Five model (McCrae \& Costa, 1989) to the Myers-Briggs Type Indicator (Myers \& McCaulley, 1985) (MBTI) typology and the Eysenck Personality Questionnaire (Eysenck \& Eysenck, 1975) (EPQ) model. Two categorizations of the way people connect to the outside world are related to extroversion and introversion (Myers, 2003).

Extroverts are engrossed in what is going on around them over their opinions and feelings. On the whole, extroverts certainly seek for inspiration outside themselves, and their energy alignment is concerning the outer world (Myers, 2003). As stated by Vandenbos (2006), extroverts are affected by the environment around them more than by themselves. Extroversion is a direction of personal interests towards the environment around the people and objects rather than the world around the personal experience. Seven features of personality that depend on extrovert dimensions are mentioned as activity, sociability, risk-taking, impulsiveness, expressiveness, practicality, and irresponsibility. The explanations are described as follow (Eysenck, 1973, as cited in Samini, 2004, p. 13) (Wafiqoh, 2019, pp. 26-27):

a) Activity

The person who has high activity tends to be active and energetic likes to do physical activities. He gets up early, does the activities quickly and different kinds of tasks.

b) Sociability

A man having high extroversion usually has high sociability. He has many friends easily, likes to go to a party, likes to do the social activity, likes to meet new friends and feels happy in friendly condition.

c) Risk Taking

Human being having high risk-taking value likes to live in dangerous situation and seek jobs that ignore the risk. He does the jobs without paying attention on his own safety.

d) Impulsiveness

The person who has this value likes to do something spontaneously without thinking firstly and make a quick decision.

e) Expressiveness

People having high expressiveness tend to their feeling freely. They usually like to show their emotions such as sad, angry, afraid, and pleasant. They show that they have high extroversion.

f) Practicality

People who have this value usually are pleasant to do practical things and not patient to do abstract and imaginative activities.

g) Irresponsibility

The man having high value on this aspect dislikes doing formal duty. He is dynamic and irresponsible in doing activities that relate to social dimension.

Conversely, introverts are fascinated by their opinions and feelings other than in issues concerning their outer world, and they are almost reluctant and unenthusiastic to speak or involve in doing tasks with others. Particularly, introvert persons have enough internal stimulation, so that they do not need further stimulus, and their alignment of energy is toward an internal world (Myers, 2003). Concisely, extroverts take the attitude of living, and comprehend it; nevertheless, introverts wish to recognize it in advance (Myers, 2003). According to Vandenbos (2006), introverts are somewhat retiring, inhibited, reserved, silent and thoughtful. They may like to reduce or protect a positive outlook, assume more doubtful views or situations, and tend to work autonomously. Extroverts, in contrast to introverts, have weak self-consciousness, in the face of suffering; for example, in a car crash, their intelligences don not keep them fast enough; as a result, they will not be able to remember easily. Rather, they are extremely ready and acquire appropriately, and consequently think of everything that takes place (Boeree, 2006). In addition, Eysenck (2004) pointed out that there are seven aspects of personality that are based on the extrovert dimension. They are inactivity, unsociability, carefulness, 
control, inhibition, reflectiveness, and responsibility. The explanations are to be as follow (Eysenck, 1973, as cited in Samini, 2004, p. 15) (Wafiqoh, 2019, pp. 30-32):

a) Inactivity

It relates to physical activities. Person having this value does the task slowly. He is also tired and easy to sleep.

b) Unsociability

People having unsociability tend to have a few close friends and like doing independent activities such as

reading. They sometimes feel stressed in interacting with others.

c) Carefulness

It is usual that person who has this value does the activities carefully. He avoids from dangerous things and does something that is familiar and safe.

d) Controlled acting.

The person plans and arranges the program before doing something. He plans his bright future and thinks before

e) Inhibition

People do not like to express their feelings freely. They are not easy to feel angry and calm.

f) Reflectiveness

The person likes to make abstracts and interpretation, discusses, and answers the philosophical question.

g) Responsibility

People who have this character will be believed by others easily. They do duties well and always fulfill inner conviction.

Some beliefs argue that introversion is a problem in the personality trait, not completely accepted. From psychological point of view, introvert concept can be an avoidable problem in personal behavior similar to introvert personality. For this reason, it is not a good justification for using the terms introvert personality disorder and avoidant personality disorder synonymously. These concepts have quite a few differences, the most outstanding difference is that introverts don't suffer from anxiety attacks when they are supposed to connect with other people socially which is absolutely unlike the persons with the avoidable personality disorder. However, some psychologists take an advice to be partly introverted especially when it deals with your daily activities attributed to the personality disorder (Naik, 2010).

Extroversion and introversion have been highly studied from the biological and the social viewpoints (Wilson \& Languis, 1990, as cited in Altunel, 2015). Saleh (1997) declared that it is important to take account of the biological alterations, particularly the brain processing variations between diverse personality types for investigating the association between personality types and language learning developments accurately as well as their results. Therefore, the relationship between personality types and language learning as regards brain processing is understood from a new comprehensive perspective. The pioneer who investigates the relation between personality types and their biological sources was Eysenck (1967, as cited in Altunel, 2015). He stated that the being sociable, cooperative, outgoing, perception seeking, communicative, act first, think later, and a hate of being alone are the usual personalities of extroverts; however, introverts are explained as being private, reclusive, quiet, reserved, sensitive, inward, think before acting, and exhausted by groups. The importance of the Individual differences can more be felt in second language acquisition and use in our native language. Studies have demonstrated the most unusual and attractive personality trait for researchers in the second language acquisition is considered to be extroversion/introversion (Dornyei, 2005). Acquiring a second language is a complicated task, which will be influenced by linguistic and non-linguistic factors (Gass \& Selinker, 2001).

The link between the personality traits and educational performance has been explored progressively. Typically, these kinds of studies have examined the correlations between personality and evaluations of school or university, such as final exam or continuous assessment (Chamorro-Premuzik, 2007). Zuckerman (2005) stated that,

Eysenck regarded introversion and extroversion as a normal dimension independent of and uncorrelated with neuroticism. He used the statistical method of factor analysis to define dimensions of personality. Eysenck define E trait in terms of items measuring two factors: sociability and impulsivity (p. 88).

Moreover, Matthews (1992) confirmed that there are differences between introverts and extroverts concerning shortterm memory, in which he prepares more evidence to show extroverts are better when storing multiple verbal inputs. In addition, Matthews claimed that extroverts perform better in high-stimulation environments with better oral processing functions, faster information retrieval from memory, and a higher resistance degree to physiological stress. Many researchers reported that extroverts and introverts differ from each other in the second language research. As Ellis (2008) mentioned,

Extroversion is viewed as a factor having a positive effect on the development of L2 basic interpersonal skills, as extroverted learners are likely to interact more and more easily with other speakers of the second language. However, introspective learners may also experience an advantage: they may find it easier to study the L2 and thereby develop higher levels of cognitive academic language proficiency (p. 541).

Many classroom teachers emphasize that extrovert students are successful in L2 learning more than their introvert counterparts, especially in the communicative aspects of language ability (Lightbown \& Spada, 2013). Recognizing personality variations in language learning is not only limited to instructors or scholars. Based on the interview results 
made by Barron-Hauwaert (2010), it is shown parents argue that extroverts take a benefit of their children since it would provide them with more chance to exercise and involve in the process of language. Moreover, a common belief exists that extroverts and introverts have differences in L2 learning, with an advantage to extroverts. According to Laney (2002), introverts are stimulated by their inner ideas, thoughts, and feelings. They should search for a peaceful place in which they recharge themselves or reflect. Introverts freely get exhausted or over-stimulated. Introverts reach their open-mindedness levels much faster than extroverts when they are subjected to mental stimulation: They will open and close the eyes faster, or turn the volume down faster (Eysenck, 1992).

\section{RESULTS AND DISCUSSION}

\section{A. Introversion vs. Extraversion - Social and Behavioral Differences}

Behavioral introverts and extraverts' tendencies emerge from using different brain pathways which influence the direction of internally or externally peoples' focus (Laney, 2002). In addition, Laney stated that introverts and extraverts differ regarding three distinctive features that can be easily observed in the classroom. The first difference manifests how they create and restore energy; however, the former should look inwards in the search for necessary power to recharge themselves that originates from the inner world of impressions, ideas or emotions, and the latter is stimulated by the external world. This can describe why introverted learners manage to avoid social contact and go for work individually, while extraverts look for the company of other students. Furnham and Stbrac (2002) stated that favorite music leads to a stronger distracting effect on the performance of introverts on different cognitive tasks more than on the performance of extroverts. Introverts wish to spend further time alone, reading books, writing poems, painting pictures, or thinking (Wallace, 2000). Introverted students tend to be inspired remarkably by their own ideas and feelings in East Asian countries.

As Eysenck (1995) stated, extroverts enjoyed social interaction and physical pursuits, and also indicated a greater tendency in stimulating activities and unusual situations, with fewer trends towards avoiding stressful situations. Attractively, most of the contemporary trait theories contain the intro-extra aspect and also have genuinely similar construct conceptualizations. De Raad (2000) proved such a view by the fact that no single pair of personality traits has thoroughly been discussed and studied so widely as that of extroversion and introversion. The introversion and extraversion conceptualizations have been developed during centuries by different theoreticians in the personality research field. Jung (1917, as cited in De Raad, 2000) initially attempted to define constructs. He proposed that Extraversion is the apparent turning of mental and intellectual energy to the external world while introversion refers to the inner stream of intellectual energy towards the complexities of the mind. The previous trait includes those who are specifically interested in people and events in the external world, while the latter presents individuals who show a keen interest in their own psyche and promote to be on their own. People who advocated the Eysenck's theory have traditionally predicted introverts as better learners because they are believed to concentrate mentally more than extrovert. Furthermore, the arousal principle has also been related to lessons of retention, the processing capacity of which may well be essential in learning (Daele, 2005).

\section{B. Extroversion/ Introversion Study Habits}

Classroom activities like writing, reading, and conducting research might become demanding tasks because these activities are assumed as solitary endeavors. Still, extroverted students can perform higher academic achievement as studying with a friend. Additionally, they can come through learning activities, which have tangible results and involve communications with other people (Pornsakulvanich et al., 2012; Pashler et al., 2008). Conversely, Davis (2006) and Sharp (2008) declared that introverted students are triggered by the inner world of thought, reflection, and observation. They guide their attention inwards and receive energy from reflective thoughts, feelings, and memories. They are sociable; however, introverted learners require space, and time alone to collect themselves. Introverted students try to understand the world, and prefer to recognize things before they can talk about them. According to Sadeghi (2012) and Sharp (2008), introverted students can learn perfect through quiet and thoughtful reflection. Their attention continues inward to their own ideas, thoughts, and impressions. Regarding classroom activities, introverted types tend appreciating reading, written, lectures, and research tasks in verbalized work. They also tend to be self-supporting and prefer to work independently. The introverted types need time to process internally. Therefore, they could confront difficulties with professors who speak too quickly and do not have time for mental processing. In addition, introverted learners are not almost comfortable to discuss in groups, and might hesitate to speak in class. Nevertheless, they are superior as working independently, incorporate their own thoughts through listening, reading, observing, writing, and independently performing research. Furthermore, the introverted type needs enough time to finish their work. They still feel more comfortable when they are not enforced to speak in class but are favored to contribute voluntarily (Molinuevo \& Torrubia, 2013).

\section{CONCLUSION}

It can be concluded, from the details in the above sections, that individual differences between learners play a crucial role in achieving a second language. Though, despite the efforts of many scientists to come up with a definitive theory 
in this regard, their success has been ruined. It can be supposed that the increase in awareness of need to pay attention to the students and their individualities in learning the language encourage the need to study the process precisely and empirically. To sum it up, in line with Issacs (2009), extroverts and introverts mainly differ in the way they receive their energy. External sources help the extrovert in the process of getting energized, whereas, internal stimulations such as emotions, ideas, and impressions helps the introverts in gaining energy. These two personality types differ in the way they react in case of receiving external stimulation. An extrovert seeks for variety in the material presented and tries to take an active role. The introvert behaves in a passive manner and prefers fewer topics presented in more depth. Moreover, present instructors and professors as well as teacher education programs should have the awareness of individual differences and personality types. Being conscious of these alterations will cause a more varied, comfortable syllabus in the process of language teaching and in conclusion enhance instructional approaches. It is insufficient to know there are different learners, and the instructor should be competent to assist students in these differences to acquire a second language. Therefore, we hope that the study of individual differences and their pedagogical implications and this review of literature may be contributed to the notion that personality types, namely extrovert and introvert affect language learning.

\section{REFERENCES}

[1] Ahour, T., \& Nourzad Haradasht, P. (2014). The comparative effect of using competitive and cooperative learning on the reading comprehension of introvert and extrovert EFL learners. Advances in language and literary studies, 5 (4), 206-215.

[2] Altunel, V. (2015). The Impact of extroversion and introversion on language learning in an input-based EFL setting (Doctoral dissertation, University of Kansas).

[3] Barron-Hauwaert, S. (2010). Bilingual siblings: Language use in families. UK: Multilingual Matters.

[4] Boeree, C. J. (2006). Personality theories. Retrieved May 1, 2020, from http://www.social-psychology.de/do/pt_intro.pdf.

[5] Boyle, G. J., Matthews, G., \& Saklofske, D. H. (2008). The Sage handbook of personality theory and assessment. London: Sage Publications Ltd.

[6] Brown, H. D. (2000). Principles of language learning and teaching. San Francisco: Addison Wesley Longman.

[7] Cervone, D., \& Pervin, L. A. (2010). Personality: Theory and research (11th ed.). New York, NY: Wiley.

[8] Chamorro-Premuzic, T. (2007). Personality and individual differences. Oxford: Blackwell.

[9] Cook, V. (2002). Portraits of the L2 user: Second language acquisition. Clevedon: Multilingual Matters Ltd.

[10] Coon, D., \& Mitterer, J. O. (2009). Psychology modules for active learning. Belmont, CA: Thomson Learning.

[11] Craighead. W. E., \& Nemeroff, C. B. (2004). The concise Corsini encyclopedia of psychology and behavioral science. Hoboken, NJ: John Willey \& Sons.

[12] Daele, S. V. (2005). The effect of extraversion on L2 oral proficiency. Retrieved April 1, 2020, from www.ucm.es/info/circulo/no24/ vandaele.htm.

[13] Davis, G.A. (2006). Learning style and personality type preferences of community development extension educators. Journal of agricultural education, 47 (1), 90-99.

[14] De Raad, B. (2000). The big five personality factors: The psycholexical approach to personality. Seattle: Hogrefe and Huber Publishers.

[15] Deutsch, M., Coleman, P. T., \& Marcus, E. C. (2006). The handbook of conflict resolution: Theory and practice. San Francisco: Jossey-Bass.

[16] Dornyei, Z. (2005). The psychology of the language learner: Individual differences in second language acquisition. Mahwah, NJ: Lawrence Erlbaum Associates.

[17] Ellis, R. (2008). Individual differences in second language learning. In A. Davies \& C. Elder (Eds.). The handbook of applied linguistics (pp. 525-551). Oxford, UK: Blackwell Publishing Ltd.

[18] Eyenck, H. J. (1973). Eysenck on extroversion. London: Crosby, Lockwood Staples.

[19] Eysenck, H. J. (1992). A reply to Costa and McCrae. P or A and C - the role of theory. Personality and Individual Differences, 13(8), 867-868.

[20] Eysenck, H. J. (1995). Genius: The natural history of creativity (Vol. 12). UK: Cambridge University Press.

[21] Eysenck, M. W. (2004). Applied cognitive psychology: Implications of cognitive psychology for clinical psychology and psychotherapy. Journal of clinical psychology, 60(4), 393-404.

[22] Eysenck, H. J., \& Eysenck, S. B. G. (1975). Manual of the Eysenck Personality Questionnaire (Adult and Junior). London: Hodder and Stoughton.

[23] Furnham, A., \& Stbrac, L. (2002). Music is as distracting as noise: The differential distraction of background music and noise on the cognitive test performance of introverts and extroverts. Ergonomics, 45(3), 203-217.

[24] Gass, S. M., \& Selinker, L. (2001). Second language acquisition an introductory course. Mahwah, NJ: Lawrence Erlbaum Associates.

[25] Issacs, T. (2009). Teaching and learning of introverted students. Open University System, Polytechnic University of the Philippines. Retrieved Jan., 25, 2020, from http://www.facultyfocus.com/articles/teaching-and-learning/introverted-studentsinthe-classroom-how-to-bring-out-their best/

[26] Laney, M. (2002). The introverted advantage: How to thrive in an extrovert world. New York, NY: Workman.

[27] Lightbown, P. M., \& Spada, N. (2013). How languages are learned (4th ed.). Oxford: Oxford University Press.

[28] Matthews, G. (1992). Extraversion. In D. M. J. P. A. Smith (Ed.), Handbook of human performance: State and trait (Vol. 3, pp. 367-396). London: Academic Press.

[29] McCrae, R. R., \& Costa, P.T. Jr. (1989). Reinterpreting the Myers-Briggs Type Indicator from the perspective of the five factor model of personality. Journal of Personality, 57, 17-40.

[30] Molinuevo, B., \& Torrubia, R. (2013). Does personality predict students' attitudes to learning communication skills? 
International Journal of Medical Education, 4(2), 155-161.

[31] Montero, R. L., Chaves, M. J. Q., \& Alvarado, J. S. (2014). Social factors involved in second language learning: A case study from the pacific campus, Universidad de Costa Rica. Revista de Lenguas Modernas, 20, 435-451.

[32] Muñoz, C. (2002). Learning languages. Barcelona: Paidós.

[33] Myers, I. B. (2003). MBTI manual: a guide to the development and use of the Myers-briggs type indicator (3rd ed.). Mountain View, California: CPP.

[34] Myers, I. B., \& McCaulley, M. H. (1985). Manual: A guide to the development and use of the Myers-briggs type indicator. Palo Alto: Consulting Psychologists Press.

[35] Naik, A. (2010). Introvert personality. Retrieved March 10, 2020, from https://buzzle.com/article/introvertpersonality.html

[36] Pashler, H., McDaniel, M., Rohrer, D.G., \& Bjork, R. (2008). Learning styles: Concepts and evidence. Psychological science in the public interest, 9 (3), 105-19.

[37] Pornsakulvanich, V., Dumrongsiri, N., \& Sajampun, P. (2012). An analysis of personality traits and learning styles as predictors of academic performance. ABAC journal, 32(3), 1-19.

[38] Sadeghi, M. (2012). The effects of cooperative learning on critical thinking in an academic context, Journal of psychological and educational research, 20 (2), 15-30.

[39] Saleh, A. (1997). The nexus of brain hemisphericity, personality types, temperaments, learning styles, learning strategies, gender, majors, and cultures. University of Alabama.

[40] Samini. (2004). The correlation between extrovert and speaking skill of students at central English course in Gemolong Sragen. Unpublished Research Paper. Surakarta: UMS.

[41] Sharp, A. (2008). Personality and second language learning. Asian social science, 4(2), 17-25. Retrieved March 2, 2020, from ccsenet.org/journal/index.php/ass/article/view.

[42] VandenBos, G.R. (2006). APA Dictionary of Psychology. Washington, DC: American Psychological Association.

[43] Wafiqoh, H. (2019). Learning strategies based on students' personality in speaking ability at the eighth grade on MTsN 1 Karanganyar (Undergraduate degree Thesis). Retrieved May 17, 2020, from https://core.ac.uk/download/pdf/296480697.pdf. (15.32.2.1.031).

[44] Wallace, M. (2000). Nurturing nonconformists. Educational leadership, 57(2), 44-60.

[45] Zafar, S., \& Meenakshi, K. (2012). Individual Learner Differences and Second Language Acquisition: A Review. Journal of Language Teaching and Research, 3(4), 639-646.

[46] Zuckerman, M. (2005). Psychobiology of personality. Cambridge: Cambridge University Press.

Maryam Cheraghi Shehni is a Ph.D candidate of Applied Linguistics at Department of Language Teaching and Translation Studies at Islamic Azad University, Varamin-Pishva branch, Iran. She is currently an English Language teacher. Her current research interests include Teacher education, Reading, CALL, ESP and Reflective teaching. Email Address: shehni.mary@ gmail.com

Tahereh Khezrab is a PhD candidate in Applied Linguistics. She completed her studies in Translation Studies for B.A. and M.A. degrees. Presently, she is a lecturer in the field of Translation Studies at Islamic Azad University, South Tehran campus and an official English Expert of Tehran Justice Administration. Her current research interests constitute teaching translation, legal and business translation and interpreting as well as ESP and CALL in these fields of study. Email Address: ta.khezrab@gmail.com 